\title{
Pengaruh Strategi Flow Proof pada Perkuliahan Struktur Aljabar terhadap Kemampuan Mahasiswa dalam Menganalisis Pembuktian
}

\author{
Scristia $^{1^{*}}$, M. Yusup ${ }^{2}$, Cecil Hiltrimartin ${ }^{3}$ \\ 1,2,3 Universitas Sriwijaya, Palembang, Sumatera Selatan 30139, Indonesia
}

Pengiriman: 30/November 2020; Diterima: 25/Maret/2021; Publikasi: 31/Maret/2021

DOI: https://doi.org/10.31629/jg.v6i1.2782

\begin{abstract}
Abstrak
Struktur Aljabar mempelajari gabungan satu atau lebih himpunan dengan satu atau lebih operasi biner yang memenuhi kumpulan aksioma. Calon guru semester lima yang menjadi subjek dalam penelitian ini harus memiliki definisi dan aksioma untuk melakukan proses analisis pendahuluan terhadap teorema-teorema untuk dibuktikan. Kesulitan mahasiswa dalam menyusun bukti pada materi Struktur Aljabar adalah menelaah pembuktian, dan melihat hubungan antara definisi dan teorema yang ada. Solusi yang diberikan berdasarkan karakteristik masalah dalam struktur aljabar adalah dengan menggunakan strategi flow proof dalam penyusunan analisis pendahuluan. Dengan menggunakan desain Quasy Experiment type One group pretest-postest design, hasil penelitian menunjukkan bahwa terdapat pengaruh strategi flow proof terhadap kemampuan analisis pendahuluan mahasiswa calon guru.
\end{abstract}

Kata kunci: flow proof; konstruksi bukti

\begin{abstract}
Algebraic Structures study the incorporates one or more sets with one or more binary operations satisfying a collection of axioms. Prospective teachers in the fifth semester who are subjects in this research must have definitions and theorems to carry out the preliminary analysis process of the theorems to be proven. Based on the preliminary analysis, students construct the proof. The solution given based on the characteristics of the problem in the algebraic structure is to use the flow proof strategy in the preparation of the preliminary analysis. By using the Quasy Experiment type pretesy-posttest groupdesign, the results showed that the flow proof strategy could improve prospective teachers' ability to analyze.
\end{abstract}

Keywords: flow proof; proof construction

\section{Pendahuluan}

Pembuktian matematis adalah suatu metode yang digunakan untuk meyakinkan kebenaran dari suatu pernyataan dengan menyusun argumen-argumen logis yang berasal dari teorema, postulat dan definisi dari matematika. Agar bukti tersebut bersifat logis maka dalam melakukan pembuktian semua langkah pada proses pembuktian harus didasarkan pada langkah sebelumnya. Dalam artian, kebenaran sebuah pernyataan matematika dianggap sebagai konsekuensi logis dari definisi, aksioma, atau pernyataan lain yang sebelumnya telah dibuktikan benar. Proses membuktikan 


\section{JURNAL GANTANG. Maret 2021; VI(1): 39 - 45 \\ p-ISSN. 2503-0671 \\ e-ISSN. 2548-5547}

inilah yang harus dimiliki oleh mahasiswa pendidikan matematika, artinya proses berpikir dalam menganalisis pembuktian perlu dilakukan oleh mahasiswa untuk membangun fakta dalam matematika dengan pasti dan menunjukkan kebenaran dari fakta tersebut (Hanna, 2000; Knuth, 2002; Ko \& Knuth, 2009; Nadlifah \& Prabawanto, 2017; Syafri, 2019). Adapun tujuan dari pembuktian dalam matematika adalah untuk meningkatkan kemampuan mahasiswa dalam memahami matematika, membangun matematika serta untuk berkomunikasi dengan matematika. Lulusan sarjana Pendidikan Matematika FKIP Universitas Sriwijaya diharapkan dapat memiliki kemampuan tersebut, dengan diberikannya mata kuliah Struktur Aljabar.

Struktur Aljabar merupakan salah satu mata kuliah yang diperlukan oleh mahasiswa calon guru matematika, yang membahas tentang suatu himpunan yang tidak kosong yang dilengkapi dengan satu atau dua operasi. Materi Struktur Aljabar berisikan tentang definisidefinisi dan teorema-teorema yang harus dibuktikan secara analisis. Seperti pada contoh berikut:

Jika $(G, *)$ suatu grup, dan e adalah elemen identitas $G$ terhadap operasi $*$, buktikan jika $a, b \in G$ dan $a^{-1}=b^{-1}$ maka $a=b$

Dari hasil observasi selama mengajar dikelas Struktur Aljabar mahasiswa mengalami kesulitan yang serius dalam membangun atau mengkontruksi bukti, mahasiswa sulit ketika menelaah pembuktian, dan melihat hubungan antara definisi dan teorema yang ada. Karena untuk membuktikan pernyataan seperti pada contoh tersebut mahasiswa harus memahami definisi dari suatu Grup, memahami teorema yang menyatakan invers dari invers suatu anggota $a$ adalah $a$ atau ditulis $\forall a \in G,\left(a^{-1}\right)^{-1}=a$. Dengan kata lain, mahasiswa harus melakukan analisis pendahuluan terlebih dahulu dalam mengkonstruksi bukti tersebut.

Tetapi kemampuan dalam menganalisis itulah yang menjadi permasalahan bagi mahasiswa, seperti yang telah dilakukan dalam penelitian sebelumnya (Nurfadilah, Hapizah, \& Scristia, 2020; Sari, Hapizah, \& Scristia, 2020) pada siswa sekolah menengah tentang konstruksi bukti, ternyata dari tingkat sekolah menengah sebelum masuk perguruan tinggi siswa telah mengalami kesulitan dalam mengkontruksi bukti terhadap suatu pernyataan. Dan berdasarkan saran dari penelitian yang telah dilakukan oleh (Jessica, Hapizah, \& Scristia, 2020; Nurfadilah et al., 2020; Sari et al., 2020; Sumarni, Hapizah, \& Scristia, 2020) yang dapat dilakukan untuk membantu siswa dalam mengkonstruksi bukti adalah dengan menerapkan strategi yang mengajak siswa menganalisis terlebih dahulu apa yang harus dibuktikan kemudian menuliskannya diselembar kertas kemudian menganalisis apa yang diperlukan untuk sampai pada bukti akhir, baik itu teorema sebelumnya yang telah terbukti benar, atau definisi-definisi yang menunjang bukti kita. Ditulis dalam selembar kertas lain inilah yang menjadi analisis pendahuluan sebelum kita menulis bukti dengan formal.

Flow Proof adalah salah satu cara untuk menyajikan bukti dengan diagram alur (Helma, 2019), serta dapat memudahkan mahasiswa dalam mengkonstruksi bukti (Larson, 2011). Karena konstruksi bukti merupakan kemampuan penting untuk siapa saja yang terlibat dengan matematika (Ko \& Knuth, 2009; Weber, 2001). Langkahlangkah dalam membuktikan dengan Flow Proof adalah menganalisis informasi yang ada dan mencari informasi tambahan yang diperlukan untuk mengkonstruksi bukti (Larson, 2011). Dalam mengkonstruksi bukti dengan Flow Proof mahasiswa berpikir ke atas dan ke bawah untuk menghubungkan antara konjektur dan kesimpulan (Miyazaki Fujita, T., \& Jones, 2012).

Penelitian yang telah dilakukan pada tahun sebelumnya oleh (Sumarni et al., 2020) dan (Scristia, Hapizah, Sumarni, \& Araiku, 2020) terkait dengan pembuktian adalah menerapkan strategi Flow Proof dalam proses pembuktian matematika, hasilnya berdampak sangat baik terhadap kemampuan peserta didik di bangku sekolah menengah dalam mengkonstruksi bukti. Hal ini dikarenakan proses Flow Proof dimulai 
dengan menganalisis apa yang diketahui dari permasalahan yang ada, dan disajikan dalam bentuk Flowchart, dan mengandung tiga unsur yaitu pernyataan, argumen, dan keyakinan. (Linares, 2006) mengungkapkan bahwa siswa lebih berhasil dalam menyusun bukti dengan menggunakan flow proof dibandingkan dengan two column proof. Dari beberapa penelitian terkait strategi Flow Proof, belum ditemukan penelitian yang menerapkan strategi Flow Proof untuk membantu mahasiswa melakukan analisis pembuktian. Masih terbatas pada penggunaan strategi dalam proses pembelajaran kemudian dilihat bagaimana kemampuan pembuktian siswa, tetapi tidak fokus dalam membantu siswa melakukan analisis pendahuluan yang menjadi masalah sulitnya mahasiswa dikelas Struktur Aljabar.

Berdasarkan permasalahan yang terdapat pada perkuliahan Struktur Aljabar yang telah dibahas sebelumnya, solusi yang dapat digunakan adalah penggunaan strategi flow proof dalam melakukan analisis pendahuluan pada proses pembuktian. Hal ini diduga dapat mengatasi masalah mahasiswa pada perkuliahan Struktur Aljabar sehingga akan membantu mahasiswa dalam menstrukturkan pola pikir secara logis. Dengan demikian, tujuan dari penelitian ini adalah untuk melihat pengaruh strategi Flow Proof dalam meningkatkan analisis pembuktian pada perkuliahan Struktur Aljabar.

\section{Metode Penelitian}

Penelitian ini merupakan penelitian quasi experiment, yaitu penelitian eksperimen yang dilaksanakan pada satu kelompok saja dengan menggunakan desain One Group pretest-postest Design, yaitu penelitian eksperimen yang dilaksanakan pada satu kelompok saja yang dipilih secara random dan tidak dilakukan tes kestabilan dan kejelasan keadaan kelompok sebelum diberi perlakuan. Desain penelitian One Group pretest-postest Design dipilih karena penelitian dilakukan dalam masa pandemi Covid19 sehingga kelas Struktur Aljabar digabung menjadi satu kelas. Subjek penelitian terdiri dari 54 mahasiswa Program Studi Matematika pendidikan matematika semester 5 .

Pada penelitian ini selama proses pembelajaran digunakan strategi Flow Proof yang disesuaikan dengan karakteristik penganalisaan dalam Struktur Aljabar. Langkahlangkah pembuktian menggunakan flow proof dalam penelitian ini yaitu (Scristia et al., 2020) : a) menuliskan kembali informasi yang diketahui dari permasalahan yang ada; b) menuliskan apa yang akan dibuktikan dari permasalahan; c) menggunakan aturan yang ada seperti postulat dan definisi ataupun teorema sebelumnya yang telah terbukti kebenarannya; d) menuliskan akibat dari aturan yang digunakan.

Format dalam flow proof berisikan sebagian simbol diantaranya tanda panah $(\rightarrow)$ yang digunakan untuk menghubungkan suatu pernyataan dengan pernyataan lain dengan suatu argumen. Untuk mencapai tujuan penelitian yang telah ditentukan dalam penelitian ini, digunakan alat pengumpul data yaitu soal pretest dan postest dalam bentuk uraian. Tes uraian berupa pernyataan-pernyataan yang harus dibuktikan kebenarannya, tes ini sangat cocok untuk melihat kemampuan analisis pembuktian mahasiswa dari setiap langkah pembuktian yang disusun oleh mahasiswa. Soal tes yang digunakan telah melewati tahap validasi expert dan hasil diskusi antara peneliti dengan team teaching mata kuliah struktur aljabar sehingga layak untuk digunakan untuk mengukur kemampuan analisis pembuktian mahasiswa.

Dari hasil pretest sebelum diterapkan strategi Flow Proof dianalisis berdasarkan pedoman penskoran kemampuan pembuktian dan hasil postest setelah diterapkan strategi Flow Proof juga dianalisis berdasarkan pedoman penskoran kemampuan pembuktian, kemudian dianalisis secara statistik untuk melihat pengaruh dari strategi Flow Proof terhadap kemampuan mahasiswa dalam menganalisis pendahuluan.

\section{Hasil dan Pembahasan}

Selama perkuliahan Struktur Aljabar, setelah diberikan definisi-definisi dan sifat-sifat pada Grup, mahasiswa diperkenalkan cara membangun flow proof dari suatu teorema atau masalah yang akan dibuktikan, hal ini dilakukan untuk melatih mahasiswa mengkonstruksi bukti, dan melakukan 
JURNAL GANTANG. Maret 2021; VI(1): $39-45$

p-ISSN. 2503-0671

e-ISSN. 2548-5547

analisis terhadap setiap argumen.

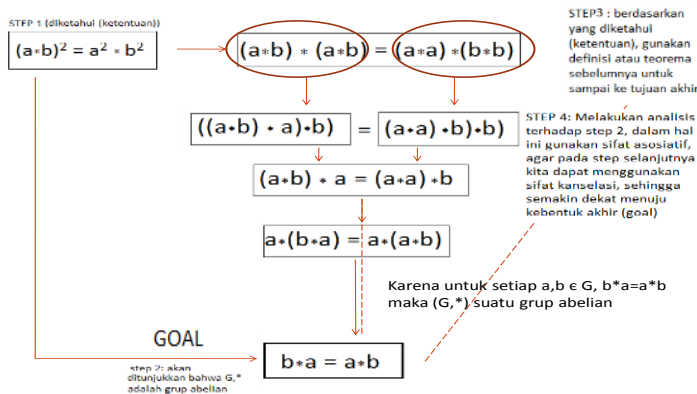

Gambar 1. Contoh flow proof

Adapun beberapa contoh flow proof yang dibuat oleh mahasiswa dapat dilihat pada Gambar 2 berikut ini.

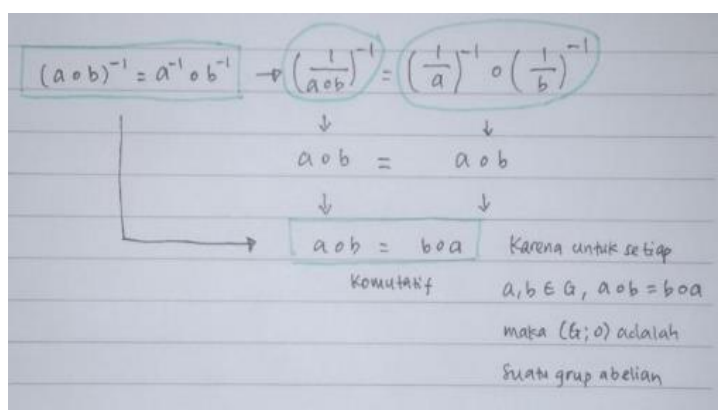

Gambar 2. Flow proof mahasiswa

Pada flow proof di Gambar 2 tampak mahasiswa mengalami kesalahan dalam memberikan argumen. Akibatnya, pernyataan pada langkah berikutnya menjadi salah.

Sebelum dilakukan proses pembelajaran mahasiswa diberikan soal pretest, dan diberikan soal tes kembali setelah melewati proses pembelajaran dengan strategi Flow Proof. Adapun nilai yang diperoleh mahasiswa pada pretest analisis pendahuluan dapat dilihat pada Gambar 3. Hasil pretest yang dicapai oleh mahasiswa belum memuaskan. Nilai rata-rata yang diperoleh 48 dengan simpangan baku 15,96. Mahasiswa sebelum melakukan pretest telah memperoleh pengetahuan tentang materi Semigrup. Semigrup beserta teorema-teoremanya dibuktikan dengan cara pembuktian yang ada pada buku struktur aljabar seperti pada umumnya.

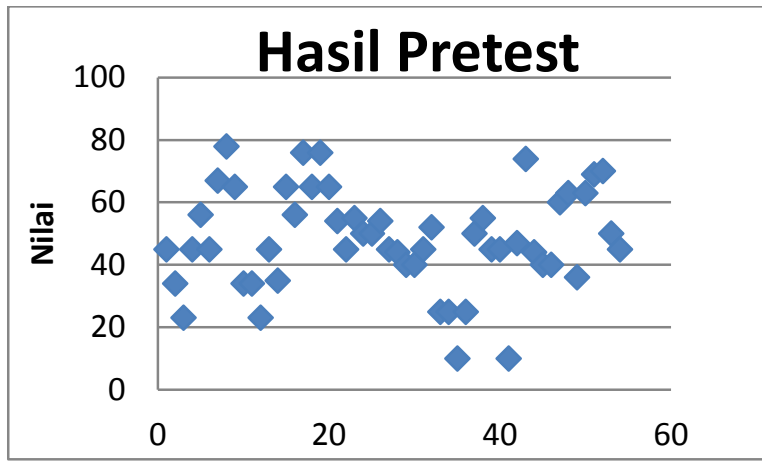

Gambar 3. Hasil pretest

Kemampuan mahasiswa dalam mengkonstruksi bukti dipengaruhi oleh analisis pendahuluan terhadap masalah yang diberikan.

Sehingga untuk membantu mahasiswa dalam melakukan analisis pendahuluan, perkuliahan struktur aljabar diterapkan strategi Flow Proof, dengan strategi ini dosen mengajak mahasiswa untuk menuliskan tujuan yang akan dibuktikan, dan mahasiswa diajak untuk berpikir maju/mundur untuk menghubungkan antara konjektur dengan kesimpulan. Setelah menerapkan startegi Flow Proof pada materi Grup, sifat-sifat grup, dan Subgrup yang membutuhkan 8 pertemuan tatap muka sinkronous. Mahasiswa diberikan kembali test yang disebut dengan postest. Adapun hasil postest mahasiswa seperti pada Gambar 4 berikut.

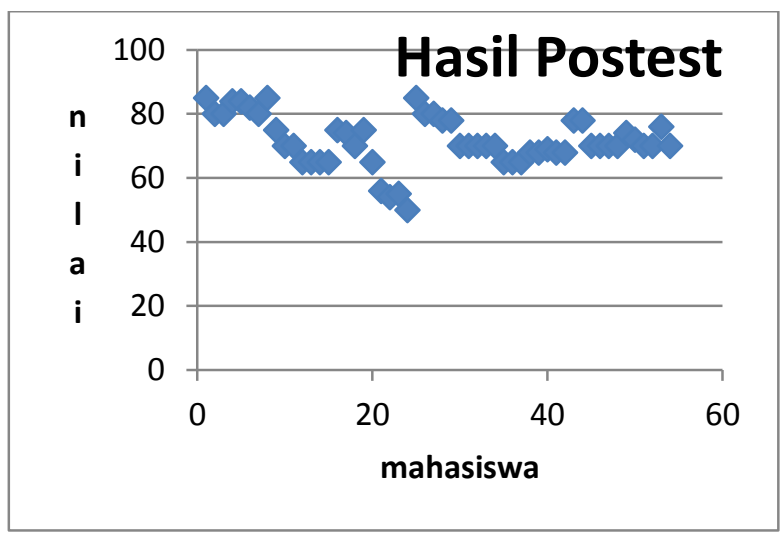

Gambar 4. Hasil postest mahasiswa

Hasil postest analisis pendahuluan yang dicapai oleh mahasiswa dipengaruhi oleh kemampuan berpikir mahasiswa yang telah distimulus selama 8 pertemuan dengan menggunakan strategi Flow Proof. Rata-rata nilai 
yang diperoleh mahasiswa adalah 71,55 dengan simpangan baku 7,86.

Tabel 1.

Ringkasan uji statistik

\begin{tabular}{lccccc}
\hline Jenis & Jumlah & \multicolumn{2}{c}{ Skor } & Uji & Uji-t \\
\cline { 3 - 4 } Tes & $\begin{array}{c}\text { Mahasiswa } \\
(\mathrm{N})\end{array}$ & $\begin{array}{c}\text { Rata- } \\
\text { rata }\end{array}$ & S.B & $\begin{array}{c}\text { Normali } \\
\text { tas }\end{array}$ & \\
(1sampel) & \\
\hline Pre & 54 & 48 & 15,96 & Normal & Terdapat \\
\hline Post & 54 & 71,55 & 7,86 & Normal & perbedaan \\
\hline
\end{tabular}

Keterangan $\alpha=0,05$

Berdasarkan Tabel 1, hasil uji beda ratarata menunjukkan terdapat perbedaan. Ini artinya terdapat peningkatan kemampuan analisis pendahuluan mahasiswa. Peningkatan tersebut tidak terlepas dari strategi yang diterapkan dari pembelajaran Struktur Aljabar yang sangat abstrak dalam melakukan pembuktian. Keikutsertaan mahasiswa dalam melakukan pembuktian menunjukkan kelebihan dari strategi Flow Proof, seperti yang diungkapkan dalam penelitian (Helma, 2019; Scristia et al., 2020) (Linares, 2006) juga mengungkapkan bahwa siswa lebih berhasil dalam menyusun bukti dengan menggunakan flow proof.

Sebagai sebuah sistem, matematika memiliki sejumlah definisi dan aturan yang harus dipatuhi untuk memperoleh hasil yang benar (Adila, Hartono, Indaryanti, Scristia, \& Yusup, 2020; Selvia, Hartono, Indaryanti, Scristia, \& Yusup, 2020). Kebenaran sebuah pernyataan matematika dianggap sebagai konsekuensi logis dari definisi, aksioma, atau pernyataanpernyataan lain yang sebelumnya sudah dibuktikan benar. Penggunaan strategi dalam pembelajaran hanyalah alat bantu untuk melakukan pembuktian, yang paling penting untuk mempermudah melakukan analisis adalah mengubah pernyataan ke dalam bentuk implikasi.

Dalam melakukan pembuktian, usaha pertama kita adalah menggunakan bukti langsung (Emeira, Hapizah, \& Scristia, 2020). Jika bukti langsung tidak berhasil, kita dapat menggunakan bukti tidak langsung. Namun, dalam penelitian ini penggunaan strategi Flow Proof masih terbatas pada pernyataan yang hanya dibuktikan dengan bukti langsung. Hal ini dikarenakan Flow Proof adalah strategi yang bergerak ke atas dan ke bawah sehingga untuk pernyataan yang tidak dapat dibuktikan dengan bukti langsung sangat sulit untuk ditentukan pilihan antara kontrapositif dan kontradiksi.

Dalam penelitian ini telah menunjukkan bahwa terdapat pengaruh penggunaan strategi Flow Proof terhadap kemampuan mahasiswa dalam menganalisis pembuktian, lebihlanjut, selama penerapan strategi Flow Proof juga menunjukkan bahwa pengetahuan mahasiswa tentang definisi, aksioma, dan teorema-teorema yang sudah ada menjadi sangat penting dalam penyusunan bukti, hal ini juga ditunjukkan oleh penelitian yang dilakukan oleh (Gabel \& Dreyfus, 2017). Mahasiswa juga harus memperhatikan dan melihat terlebih dahulu bahwa kondisi pada teorema yang akan digunakan sudah terpenuhi. Untuk itu, agar strategi Flow Proof dalam mata kuliah Struktur Aljabar dapat terlaksana dengan benar, bukti yang disusun harus berisi rencana, kegiatan yang dilakukan, dan hasil yang diperoleh dari proses bukti itu sendiri.

\section{Kesimpulan}

Kemampuan mahasiswa dalam menyusun pembuktian sangat dipengaruhi oleh analisis pendahuluan yang mahasiswa lakukan terhadap suatu pernyataan. Dari uji statistik yang dilakukan terdapat perbedaan rata-rata sebelum dan setelah diterapkan strategi Flow Proof pada perkuliahan Struktur Aljabar, hal ini menunjukkan bahwa Strategi Flow Proof memberikan pengaruh terhadap kemampuan analisis pendahuluan mahasiswa dalam melakukan analisis bukti.

Terdapat beberapa hal yang harus diperhatikan oleh mahasiswa dalam menyusun bukti yaitu pengetahuan tentang definisi, aksioma, dan teorema-teorema yang sudah ada sangatlah penting dimiliki oleh mahasiswa dalam menyusun bukti. Kedua, sebelum teorema digunakan perlu ditunjukkan terlebih dahulu bahwa kondisi dalam teorema tersebut sudah terpenuhi. 
JURNAL GANTANG. Maret 2021; VI(1): 39 - 45

p-ISSN. 2503-0671

e-ISSN. 2548-5547

\section{Referensi}

Adila, R., Hartono, Y., Indaryanti, Scristia, \& Yusup, M. (2020). The effect of creative problem-solving models on students' higher level thinking skills in linear programming. In Journal of Physics: Conference Series (Vol. 1480). Institute of Physics Publishing. https://doi.org/10.1088/17426596/1480/1/012047

Emeira, G., Hapizah, \& Scristia. (2020). Mathematical proof analysis using mathematical induction of grade XI students. In Journal of Physics: Conference Series (Vol. 1480). Institute of Physics Publishing. https://doi.org/10.1088/17426596/1480/1/012044

Gabel, M., \& Dreyfus, T. (2017). Affecting the flow of a proof by creating presence- - a case study in Number Theory. Educational Studies in Mathematics, 96(2), 187-205. https://doi.org/10.1007/s10649-016-9746-z

Hanna, G. (2000). Proof, Explanation and Exploration: An Overview. Educational Studies in Mathematics, 97(1-4), 131-141. https://doi.org/10.1023/A

Helma. (2019). Penggunaan Flow Proof pada Perkuliahan Analisis Real untuk Meningkatkan Kemampuan Mahasiswa dalam Menganalisis Pembuktian definitions and theorems to solve the problems and perform a process which is often called the preliminary analysis. After that, st, 3 .

Jessica, C., Hapizah, \& Scristia. (2020). Analysis of student's proof construction on logarithms. In Journal of Physics: Conference Series (Vol. 1480). Institute of Physics https://doi.org/10.1088/17426596/1480/1/012035

Knuth, E. J. (2002). Secondary school mathematics teachers' conceptions of proof. Journal for Research in Mathematics Education, $33(5)$. https://doi.org/10.2307/4149959

Ko, Y. Y., \& Knuth, E. (2009). Undergraduate mathematics majors' writing performance producing proofs and counterexamples about continuous functions. Journal of Mathematical Behavior, 28(1). https://doi.org/10.1016/j.jmathb.2009.04.00 5

Larson, R., Boswell, L., Kanold, Timothy D., \&
Stiff, Lee. (2011). Larson algebra 2 assesment book (common core edition). Holt McDougal.

Linares, L. (2006). The Effects of a Proof Mapping Instructional Technique on High School Geometry Students and Their Ability to Write Geometric Proofs. (Thesis, University of California)

Miyazaki Fujita, T., M., \& Jones, D. K. (2012). Introducing the structure of proof in lower secondary school geometry: a learning progression based on flow-chart proving. Icme2012, 2858-2867.

Nadlifah, M., \& Prabawanto, S. (2017). Mathematical proof construction: Students' ability in higher education. Journal of Physics: Conference Series, 895(1), 8-13. https://doi.org/10.1088/17426596/895/1/012094

Nurfadilah, F., Hapizah, \& Scristia. (2020). Analysis of student's proof construction on exponents. In Journal of Physics: Conference Series (Vol. 1480). Institute of Physics https://doi.org/10.1088/17426596/1480/1/012036

Sari, D., Hapizah, \& Scristia. (2020). Analysis of student's proof construction on matrix determinants. In Journal of Physics: Conference Series (Vol. 1480). Institute of Physics https://doi.org/10.1088/17426596/1480/1/012060

Scristia, Hapizah, Sumarni, \& Araiku, J. (2020). Flow-proof strategy in proof construction on geometry instruction. Journal of Physics: Conference Series, 1581, 012037. https://doi.org/10.1088/17426596/1581/1/012037

Selvia, N., Hartono, Y., Indaryanti, Scristia, \& Yusup, M. (2020). Students' high-level thinking skills in creative problem solving learning model. In Journal of Physics: Conference Series (Vol. 1480). Institute of Physics https://doi.org/10.1088/17426596/1480/1/012046

Sumarni, Hapizah, \& Scristia. (2020). Student's triangles congruence proving through flow proof strategy. In Journal of Physics: Conference Series (Vol. 1480). Institute of Physics Publishing. https://doi.org/10.1088/1742- 
6596/1480/1/012030

Syafri, F. S. (2019). Pengaruh kemampuan representasi siswa dalam pemecahan masalah matematika. Jurnal Pendidikan Matematika, 3(May), 49-55.

Weber, K. (2001). Student difficulty in constructing proofs: The need for strategic knowledge. Educational Studies in Mathematics, 48(1). https://doi.org/10.1023/A:1015535614355 